\title{
Ant mediated redistribution of a xyloglucanase enzyme in fungus gardens of Acromyrmex echinatior
}

\author{
Pepijn W. Kooij ${ }^{1,3^{*}}$, Jeroen W. M. Pullens ${ }^{1,2}$, Jacobus J. Boomsma ${ }^{1}$ and Morten Schiøtt ${ }^{*}$
}

\begin{abstract}
Background: Xyloglucan is an important component in plant cell walls that herbivores cannot digest without microbial symbionts. Leaf-cutting ants are major insect herbivores in the Neo-Tropics that rely on fungus-garden enzymes for degrading plant cell walls. However, many of these ants discard much of their harvested plant material after partial degradation, which has led to the hypothesis that the fungal symbionts are primarily producing cell wall degrading enzymes to gain access to intracellular nutrients rather than for obtaining sugars from recalcitrant cell wall polymers, such as (hemi-)cellulose.

Results: The fungal symbiont provides a single xyloglucanase (Xeg1) to its ant farmers by upregulating the expression of this protein in the inflated hyphal tips (gongylidia) that the ants ingest. Similar to other enzymes ingested this way, also Xeg1 is not digested but vectored to the fresh leaf-fragment pulp at the top of fungus gardens via ant fecal fluid. Xeg1 is 4-5 times more active in fecal fluid when ants ingest their normal fungal food, compared to a sucrose control diet, as expected when they cannot produce Xeg1 themselves. We confirm substrate specificity of fungal Xeg1 towards xyloglucan by heterologous expression in yeast and show that xyloglucanase activity is higher in the oldest, bottom layers of fungus gardens and in discarded debris material than in the upper and middle layers of fungus gardens.

Conclusion: Our results are consistent with Xeg1 playing a role in the initial breakdown of plant cell wall hemicellulose to provide sugars for aggressive hyphal growth before intracellular proteins become available. Xeg1 does not play a major decomposition role in the middle layer of fungus gardens where it is produced by the gongylidia. Overall high xyloglucanase activity in old mycelium that is (about to be) discarded is striking and quite possibly serves defensive purposes by precluding that competing microorganisms can grow. Our results support the hypothesis that the ant-fungus symbiosis prioritizes access to the protein-rich contents of live plant cells and that carbohydrates are not a limiting resource.
\end{abstract}

Keywords: Leaf-cutting ants, Leucoagaricus gongylophorus, Gene expression, Stoichiometry, Xyloglucan, Plant cell wall degradation, Mutualism

\section{Background}

Plant cell wall polymers are among the most abundant natural resources, but very few animals have genomes that encode enzymes with the capacity to degrade these compounds [1]. Most animals that specialize on plant-based diets, therefore, live in symbioses with microorganisms that produce these enzymes for them. Symbioses of this kind are not only common in ungulates, but also in insect

\footnotetext{
* Correspondence: p.kooij@kew.org; mschiott@bio.ku.dk

'Centre for Social Evolution, Department of Biology, Copenhagen University, Universitetsparken 15, Copenhagen DK-2100, Denmark

Full list of author information is available at the end of the article
}

lineages where feeding on dead wood, leaf litter or live plant material has evolved multiple times independently $[2,3]$. The gut symbionts involved are usually bacteria, but protists fulfill similar roles in the lower wood-dwelling termites $[4,5]$ and similar services can be provided by fungi, such as gut yeasts in several families of woodingesting beetles $[6,7]$, ambrosia fungi in wood-boring Xyleborine beetles [8], and Termitomyces fungi in fungusgrowing termites [9].

The lower attine fungus-growing ants use dead plant material to manure their fungus-gardens, which implies that these fungi must have considerable plant cell wall 
degrading capacities [10]. However, in contrast to other insect-fungus symbioses, the attine ants evolved an evolutionarily derived leaf-cutting ant lineage that relies on active herbivory. After resolving challenges of defensive secondary plant compounds [11], this advanced symbiosis gained access to vast amounts of intracellular carbohydrates, lipids and proteins that would no longer be available in dead plant cells. However, although the fungi cultivated by leaf-cutting ants have retained the capacity to degrade all major components of plant cell walls except lignin [12-20], many leaf-cutting ants discard large amounts of non-decomposed plant cell wall material from the bottoms of their fungus gardens [14, 17], suggesting that further digestion of this material is not of high priority. It has therefore been suggested that the main purpose of fungal symbiont cell wall degrading enzymes is to macerate the fresh plant tissues deposited on the top of gardens merely to gain access to more easily digestible intracellular nutrients [13, 21-23].

The two genera of leaf-cutting ants, Atta and Acromyrmex, live in obligate mutualistic symbiosis with varieties of Leucoagaricus gongylophorus [24-26]. This highly productive polyploid crop-symbiont [26] has likely been instrumental for the ants' progression to dominant herbivore status in the New World tropics $[18,27]$ with significant accelerator functions of nitrogen and phosphorus recycling in many ecosystems [28]. The phylogenetically basal "lower" attine ants rear saprotrophic fungus gardens, but the crops of leaf-cutting ants belong to a uniquely domesticated lineage that has evolved special symbiotic organs, staphylae, that grow bundles of inflated hyphal tips (gongylidia) to provide essentially all nutrition for the ants and their brood [29-31]. After the larger foraging workers have cut the leaf fragments and transported them back to the nest, smaller workers chew these pieces into a pulp, reducing the crystallinity of the plant cellulose [20,32], and place this material on top of the fungus garden before manuring it with fecal fluid and inoculating it with fresh tufts of mycelium [13].

The ant fecal fluid is involved in the rapid maceration of leaf pulp [22], and contains a wide range of fungal plant degrading enzymes such as pectinases [13], laccases [11] and proteases [33]. The genes coding for these enzymes are almost always upregulated in the gongylidia that the ants ingest and the enzymes themselves normally retain their activity after gut passage so they can be vectored to garden locations where they are most useful by the ant workers. However, gongylidia upregulation and fecal fluid expression for cellulases and hemicellulases has not been investigated previously, as these categories of enzymes were not particularly common among the ca. 36 proteins identified in the Acromyrmex echinatior fecal fluid [13]. In fact, only a single protein (Xeg1) belonging to the glycoside hydrolase family 12 was identified in the fecal fluid of Panamanian A. echinatior [13], but remained unconfirmed in a recent study on lignocellolytic enzymes in L. gongylophorus from other sympatric colonies of the same ant species [16].

Substrates targeted by the members of the GH12 enzyme family are cellulose, xyloglucan and $\beta-1,3-1,4$-glucan. Cellulose is the dominant component of both primary and secondary plant cell walls, whereas xyloglucan is the most abundant hemicellulose in the primary cell wall of dicotyledons, comprising ca. $20 \%$ of the plant cell wall dry weight [34] and having important roles in plant cell wall defenses [35]. We therefore hypothesized that the identified GH12 enzyme might have an important function in fecal fluid activity, and designed the present study to: 1 . Measure gene expression levels of xeg 1 in the different layers of the fungus garden and in the fungal gongylidia relative to normal mycelium, 2 . Identify the substrate specificity of Xeg1, 3. Confirm that Xeg1 activity in the fecal fluid is fungal derived, 4. Measure the xyloglucanase activity in both fecal fluid and fungus gardens of Acromyrmex echinatior, and 5. Discuss the implications of our findings for the ongoing discussion about the functional priorities of plant cell wall degradation by leaf-cutting ant fungus gardens.

\section{Methods \\ Biological material}

A total of seven ant colonies of Acromyrmex echinatior (Ae226, Ae263, Ae266, Ae280, Ae322, Ae335 and Ae370), collected between 2004 and 2007 in Gamboa, Panama, were used for this study. All colonies were kept under controlled conditions of ca. $25{ }^{\circ} \mathrm{C}$ and a relative humidity of ca. $70 \%$, and were fed twice a week with fresh bramble leaves (Rubus sp.), parboiled rice and pieces of apple, which they use to maintain their fungal symbiont, Lеuсоаgaricus gongylophorus.

For the collection of fecal fluid, the gaster (final abdominal segments) of a large worker was gently pressed onto a glass microscope slide using a forceps [36]. Each fecal droplet was mixed with $0.5 \mu \mathrm{l}$ demineralized and sterilized water (the fecal fluid "enzyme extract") and collected with a micropipette in an Eppendorf vial and kept on ice until further processing. Fecal fluid was collected from two different groups of large workers for each of five colonies (Ae226, Ae263, Ae266, Ae280 and Ae322), one group having access to the fungus garden and thus assumed to have ingested fungal gongylidia, and the other being deprived of their fungus garden and provided only with $10 \% \mathrm{su}$ crose water for 20 days. We further collected $120 \mathrm{mg}$ fungus garden material from each of the three visible layers of the source colony fungus garden [15], the fresh and dark top layer, the mature gongylidiaproducing middle layer [11] and the old bottom layer from five colonies (Ae226, Ae263, Ae266, Ae280 and 
Ae322). We supplemented this material with samples from the colony's debris material, i.e. old fungus garden material discarded by the ants, similar to a previous study [15] and added $500 \mu \mathrm{l}$ of demineralized and sterilized water to each sample and crushed material with a pestle before vortexing and centrifuging for $15 \mathrm{~min}$ $(15,000 \mathrm{~g})$. The fungus garden supernatant and the fecal fluid extract were then kept on ice until processing later on the same day.

For gene expression measurements in gongylidia and control mycelium, we collected garden material from five colonies (Ae263, Ae280, Ae322, Ae335 and Ae370): ca. $100 \mu \mathrm{l}$ of gongylidia clusters (staphylae) and a similar mass of normal mycelium in separate $2 \mathrm{ml}$ Eppendorf tubes floating in liquid nitrogen, using a stereomicroscope at 40x magnification. For gene expression measurements in the different fungus garden layers and the debris pile, these samples were supplemented by $120 \mathrm{mg}$ fungal material from colonies Ae226, Ae263, Ae266, Ae280 and Ae322, after carefully removing any visible ants or ant parts, larvae and eggs. All samples were stored at $-80{ }^{\circ} \mathrm{C}$ for RNA extraction at a later point.

\section{Protein identification and gene cloning}

SDS-PAGE and mass spectrometry was performed as described previously [11, 13, 33]. A mix of fifty fecal droplets was subjected to SDS-PAGE, after which individual protein bands were manually excised from the gel. Proteins were extracted from the gel plugs and digested with trypsin. De novo sequencing of the resulting peptide fragments was performed on the basis of $b$ and $y$ fragment ions present in MS/MS spectra of derivatized and underivatized samples. Amino acid sequences were obtained by manual analysis of the spectra using the software program AminoCalc (Protana A/S, Odense, Denmark) as support. The obtained amino acid sequences were used as queries in a Blast search of the assembled Acromyrmex echinatior genome [37] and a low coverage genome sequence of the Acromyrmex echinatior fungal symbiont [11].

RNA extraction and cDNA production was performed as described in Schiøtt et al. [13]. A full-length gene transcript sequence of $x e g 1$ was obtained using a RACE (Rapid Amplification of cDNA Ends) strategy. 3' and 5'-RACE libraries were made from ca. $1 \mu \mathrm{g}$ of extracted RNA with the SMART RACE cDNA kit (CLONTECH, Mountain View, California, USA), and 3'end and 5'end gene sequences were $\mathrm{PCR}$ amplified from these libraries using the gene specific primers SYT-F1 (CAG TCG ACA CTT CCC AGC ACT GTG) or SYT-R1 (GGT ATA CTG ACC AGC AGT GAC GGT G) designed from the BLASTsearch-identified sequence reads along with the UPM primer enclosed in the SMART RACE cDNA kit. The following PCR scheme was used in the RACE experiments: one cycle of $95{ }^{\circ} \mathrm{C}$ for $5 \mathrm{~min}, 10$ cycles of $95^{\circ} \mathrm{C}$ for $20 \mathrm{sec}$, $72{ }^{\circ} \mathrm{C}$ for $30 \mathrm{sec}$ (with a decrease in temperature of $0.5^{\circ} \mathrm{C}$ in every cycle) and $72{ }^{\circ} \mathrm{C}$ for $3 \mathrm{~min}$, followed by 35 cycles of $94{ }^{\circ} \mathrm{C}$ for $20 \mathrm{sec}, 67^{\circ} \mathrm{C}$ for $30 \mathrm{sec}$ and $72{ }^{\circ} \mathrm{C}$ for $3 \mathrm{~min}$, and ending with one cycle of $72{ }^{\circ} \mathrm{C}$ for $7 \mathrm{~min}$. PCR products were cloned in pCR4-TOPO using the TOPO-TA cloning procedure (Invitrogen, Carlsbad, California, USA) and sequenced at Eurofins MWG Operon (Ebersberg, Germany). The full length gene sequence is deposited in GenBank with accession number KU198622.

\section{Quantitative real-time PCR}

Primers for the xeg1 gene (Additional file 1: Table S1) were designed by matching the obtained cDNA sequences to the available genome sequence of the Acromyrmex echinatior symbiont [11] using BLASTn. Matching reads were assembled and aligned to the cDNA sequence to identify intron and exon sequences. Primers were then designed to span an intron to avoid amplification of genomic DNA. The qPCRs were run on an Mx3000P QPCR System (Agilent, Santa Clara, CA, USA) in a $20 \mu \mathrm{l}$ reaction $(0.5 \mu \mathrm{l}$ cDNA, $10 \mu \mathrm{l}$ 2x SYBR Premix Ex Taq [TaKaRa Bio Inc., Otsu, Japan] and $0.4 \mu \mathrm{l}$ of each primer $[10 \mu \mathrm{M}])$ with the following conditions: one cycle of $95{ }^{\circ} \mathrm{C}$ denaturing for 2 min, followed by 40 cycles of $95{ }^{\circ} \mathrm{C}$ denaturing for $30 \mathrm{sec}, 57^{\circ} \mathrm{C}$ annealing for $30 \mathrm{sec}$, and $72{ }^{\circ} \mathrm{C}$ extension for $30 \mathrm{sec}$ and ending with a melting curve cycle of $95^{\circ} \mathrm{C}$ for $30 \mathrm{sec}, 57^{\circ} \mathrm{C}$ for $30 \mathrm{sec}$ and $95^{\circ} \mathrm{C}$ for $30 \mathrm{sec}$.

We performed qPCR for three genes in total: the target gene xeg1 and two housekeeping genes ubiquitin ( $\mathrm{Ubc}$, GenBank HQ174771) and glyceraldehyde 3-phosphate dehydrogenase (GAPDH, GenBank HQ174770) with three technical replicates for each sample. All $\mathrm{Ct}$ values from the RT-qPCR analyses were analysed using $\mathrm{R}$ with packages "ReadqPCR" [38] and "NormqPCR" [39]. Average expression was calculated from the three technical replicates of each sample for two datasets, one with $\mathrm{Ct}$ values for the different fungus garden layers including the debris pile and the other with $\mathrm{Ct}$ values for the fungus garden mycelium and gongylidia.

Based on the primer efficiencies for all genes (xeg1: $95.6 \%$; $U b c$ : $95.8 \%$; GAPDH: $91.6 \%$ ), only $U b c$ was used as reference housekeeping gene to determine the normalized expression values for xeg1 in the fungus garden layer samples, which produced $2^{\Delta \mathrm{Ct}}$ values [40] for each layer. These results were further analysed with $\mathrm{R}$ using ANOVA to generate individual $\mathrm{p}$-values with General Linear Hypotheses ("glht") in the Simultaneous Inference in General Parametric Models package "multcomp" [41]. Ubc was also used as housekeeping gene for the gene expression comparison between gongylidia and mycelium, to calculate the relative expression levels of the $x e g 1$ gene, resulting in $2^{-\Delta \Delta \mathrm{Ct}}$ values [42]. 


\section{Heterologous expression in yeast}

Heterologous expression of the cDNA sequence of xeg1 in Saccharomyces cerevisiae was done to identify the enzymatic activity of the encoded protein. The coding sequence of the $x e g 1$ gene was PCR amplified from cDNA using the forward GH12-F1 primer 5'-AAG CTT AAA TAA TGT TCT CCA AGA AAT TGA CTG C-3' together with the reverse GH12-R1 primer 5'-TCT AGA CTA AGC GAT TGT CAC ACT ATA C-3'. PCR conditions were one cycle of $94{ }^{\circ} \mathrm{C}$ for $5 \mathrm{~min}$, then 30 cycles of $94{ }^{\circ} \mathrm{C}$ for $30 \mathrm{sec}, 55^{\circ} \mathrm{C}$ for $30 \mathrm{sec}$ and $72{ }^{\circ} \mathrm{C}$ for $1 \mathrm{~min}$, and ending with one cycle of $72{ }^{\circ} \mathrm{C}$ for $10 \mathrm{~min}$. To increase the product, the amplified cDNA was cloned in pCR4-TOPO using the TOPO TA cloning method (Invitrogen, Carlsbad, CA, USA), after which the clone was sequenced to ensure that no PCR errors had been incorporated into the construct. Through digestion and ligation steps the construct was then inserted into the yeast expression vector pYES2 (Invitrogen) under he control of a galactose inducible promoter. Saccharomyces cerevisiae strain INVSc1 (MATa his3D1 leu2 trp1-289 ura3-52, Invitrogen) was transformed with either the pYES2 vector containing the xeg1 gene (pYES2-xeg1) or an empty pYES2 vector using the LiOAc/polyethylene glycol (PEG) method [43]. As the pYES2 vector contains the URA3 gene, positive transformants could be selected by plating on a uracil depleted yeast medium consisting of $2 \%$ glucose, $2 \%$ bacto-agar, $0.7 \%$ (wt/vol) yeast nitrogen base (Invitrogen) and $0.2 \%$ yeast synthetic drop-out media supplement without uracil (Sigma- Aldrich), and incubating at $25^{\circ} \mathrm{C}$ for 7 days. $\mathrm{Ura}^{+}$ colonies were then grown in a similar medium without agar and with either $2 \%$ glucose or $2 \%$ galactose at $25{ }^{\circ} \mathrm{C}$ overnight. Yeast cells from $5 \mathrm{ml}$ cultures were harvested by centrifugation, ground in liquid nitrogen with a mortar and pestle, and dissolved in an equal amount of $50 \mathrm{mM}$ Tris $\mathrm{pH} 7.0$ to be used in an AZCL assay for four different substrates; barley $\beta$-glucan (endo- $\beta$-1,3-1,4-glucanase), HE-cellulose (endo- $\beta$-1,4-glucanase), pachyman (endo- $\beta$ 1,3 -glucanase) and xyloglucan (endo- $\beta-1,4$-xyloglucanase).

\section{Xyloglucanase activity}

Fecal fluid and fungus garden xyloglucanase activities were measured using the AZO-Xyloglucan-assay (Megazyme, Wicklow, Ireland). Xyloglucanase activity was determined by incubating $50 \mu \mathrm{l}$ enzyme extract in $100 \mu \mathrm{l}$ pre-equilibrated substrate solution, $\mathrm{pH}$ 5. The solution was vortexed and incubated for 10 minutes at $30{ }^{\circ} \mathrm{C}$ and the reaction terminated by adding $250 \mu \mathrm{l}$ of $99 \%$ ethanol. Samples were then vortexed and centrifuged for $10 \mathrm{mi}-$ nutes at $1000 \mathrm{~g}$, after which the supernatant was measured for absorbance at $590 \mathrm{~nm}$ in the Versamax ELISA micro plate reader (Molecular Devices, Sunnyvale, California, USA). The absorbance measurements were converted to enzyme units using the standard curve included in the protocol. One unit was defined as the amount of enzyme required to release $1 \mu \mathrm{g}$ of glucose per minute per fecal droplet or mg fungus garden.

\section{Results}

Mass spectrometry analysis of fecal fluid from Acromyrmex echinatior $[11,13,33]$ identified the peptide sequence SYTNJNJNAN(LNK) (in band number 12 of the SDSPAGE picture presented in an earlier publication [13]). The J can be either leucin or isoleucin which have the same mass, and the identities of the last three amino acids could not be unequivocally determined by mass spectrometry, but had a cumulated mass that fits with LNK and matched the xeg1 gene in the genome of Leucoagaricus gongylophorus $[11,17]$ and the corresponding amino acid sequence SYTNINLNANLNK. BLAST search allowed us to assign the xeg1 gene to glycoside hydrolase family 12 . Relative changes in xeg1 gene expression in gongylidia versus normal mycelium (fold-changes: $2^{-\Delta \Delta C t}$ ) showed that the gene was significantly more expressed (fold change $=$ 3.6, SE-min $-\mathrm{SE}-\max =0.48-5.30$ ) in the gongylidia than in normal mycelium $(\mathrm{z}=-5.339, p<0.00001$; Additional file 1: Table S2), indicating that ingestion of this enzyme by the ants for transfer to the fecal fluid is actively promoted by the fungal symbiont. We found no differences in normalized gene expression of the $x e g 1$ gene across the different fungus garden layers $\left(\mathrm{F}_{3,16}=1.988, p=0.156\right.$; mean \pm SE normalized fold changes per layer: top: $0.572 \pm$ 0.105 ; middle: $0.652 \pm 0.411$; bottom: $0.359 \pm 0.067$; debris material: $1.671 \pm 0.710$; Additional file 1: Table S3).

The xeg1 gene was successfully inserted into yeast using the pYES2 vector with a galactose inducible GAL1 promoter, and was subsequently found to be active only for the activated (gal+) InvSC-pYES2-xeg1 transformant on xyloglucan whereas no activity was found for the other substrates, showing that Xeg1 is indeed a xyloglucanase (Fig. 1). Furthermore, the four controls, empty InvSC, InvSC-pYES2 in glucose medium, InvSC-pYES2 in galactose medium and InvSC-pYES2-xeg1 in glucose medium showed no activity, proving that the activity of the activated (gal+) InvSC-pYES2-xeg1 transformant is indeed due to the activation of the xeg1 gene.

In order to correlate the xeg1 gene expression measurements in the gongylidia and the fungus garden layers with actual enzyme activity, we measured the xyloglucanase activity in the ant fecal fluid and in the same fungus garden layers that were used for the gene expression measurements. Fecal droplet xyloglucanase activity assays (Fig. 2) showed a substantial reduction in activity when ants had been feeding on sucrose water for 14 days $\left(\mathrm{t}_{4.943}=5.276\right.$, $p<0.01$; Additional file 1: Table S4), but some activity remained and was significantly higher than zero $\left(\mathrm{t}_{4}=\right.$ $4.018, p<0.01$ ), suggesting that gut bacteria may also produce some xyloglucanase. The xyloglucanase activities in 


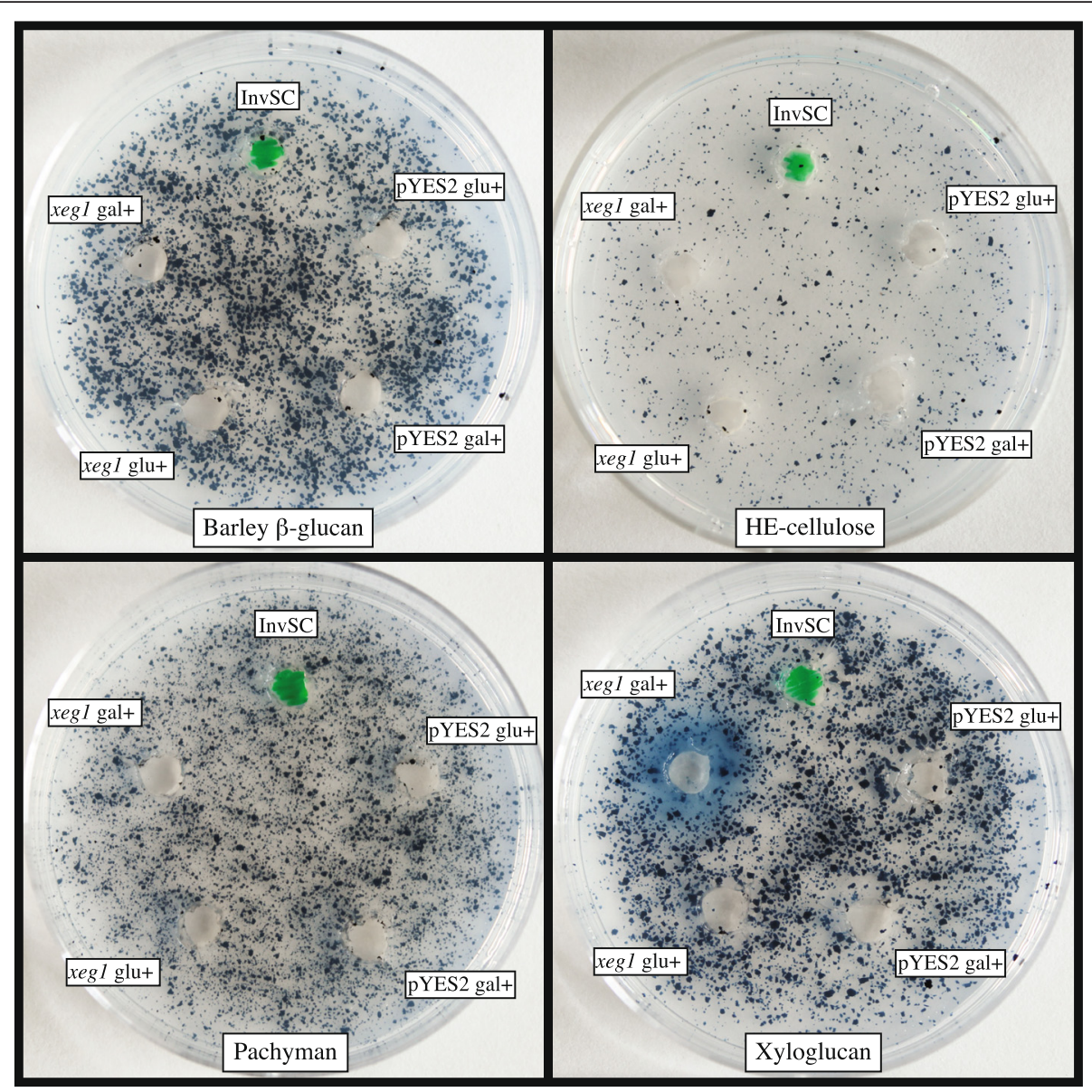

Fig. 1 Heterologous expression of xeg1 in yeast shows specificity towards xyloglucan. Enzyme activity on barley $\beta$-glucan, HE-cellulose, pachyman and xyloglucan after heterologous gene expression of xegl from fungus gardens of Acromyrmex echinatior in yeast. Tested samples are, from the top and clock-wise, empty InvSC (marked green to simplify the identification of samples after incubation), InvSC-pYES2 from glucose medium, InvSC-pYES2 from galactose medium, InvSC-pYES2-xeg1 from glucose medium and InvSC-pYES2-xeg1 from galactose medium. No activity could be detected for any of the samples except for the activated (gal+) InvSC-pYES2-xeg1, which confirmed that Xeg1 is a xyloglucanase

the different fungus garden layers increased from top to bottom/debris material $\left(\mathrm{F}_{3,12}=7.246, p<0.01\right.$, Fig. 3; Additional file 1: Table S5), with activity being slightly higher in the top compared to the middle layer, consistent with fecal droplets being placed at the top of the fungus garden. However, the highest activities were found in the bottom layer of the fungus garden and the debris material, consistent with previous findings observing a drop in the amount of xyloglucan present in fungus gardens from middle to bottom layer and from bottom layer to debris material [14].

\section{Discussion}

Breaking down live plant cell walls is a complex process, which involves multiple groups of enzymes to degrade this matrix of cellulose fibers intertwined with pectins, lignins and hemicelluloses. The enzymes normally involved are: 1. polyphenol oxidases (including laccases), which break down lignin and secondary metabolites that function as defensive compounds, 2. pectinases and hemicellulases, which open-up the matrix of the cellulose fibers, 3. proteases, which degrade cell wall proteins, and 4. cellulases that break down the long cellulose chains into single glucose molecules [34, 44]. So far, it has been shown that a special group consisting of one laccase [11], six pectinases [13] and five proteases [33] are all produced in enhanced quantities in the gongylidia of leaf-cutting ant fungal cultivars. These enzymes are now also known to pass undigested through the gut system of the ants to end up in the fecal fluid, which the ants mix with their newly collected leaf pulp when adding this to the top of fungus garden. Our present study shows that a similar scenario holds for the xyloglucanase function of the hemicellulase Xeg1, which completes a survey of tracing down all abundant enzymes isolated from the fecal droplets of A. echinatior [13] and without having found a single enzyme that targets recalcitrant cellulose or lignin. 


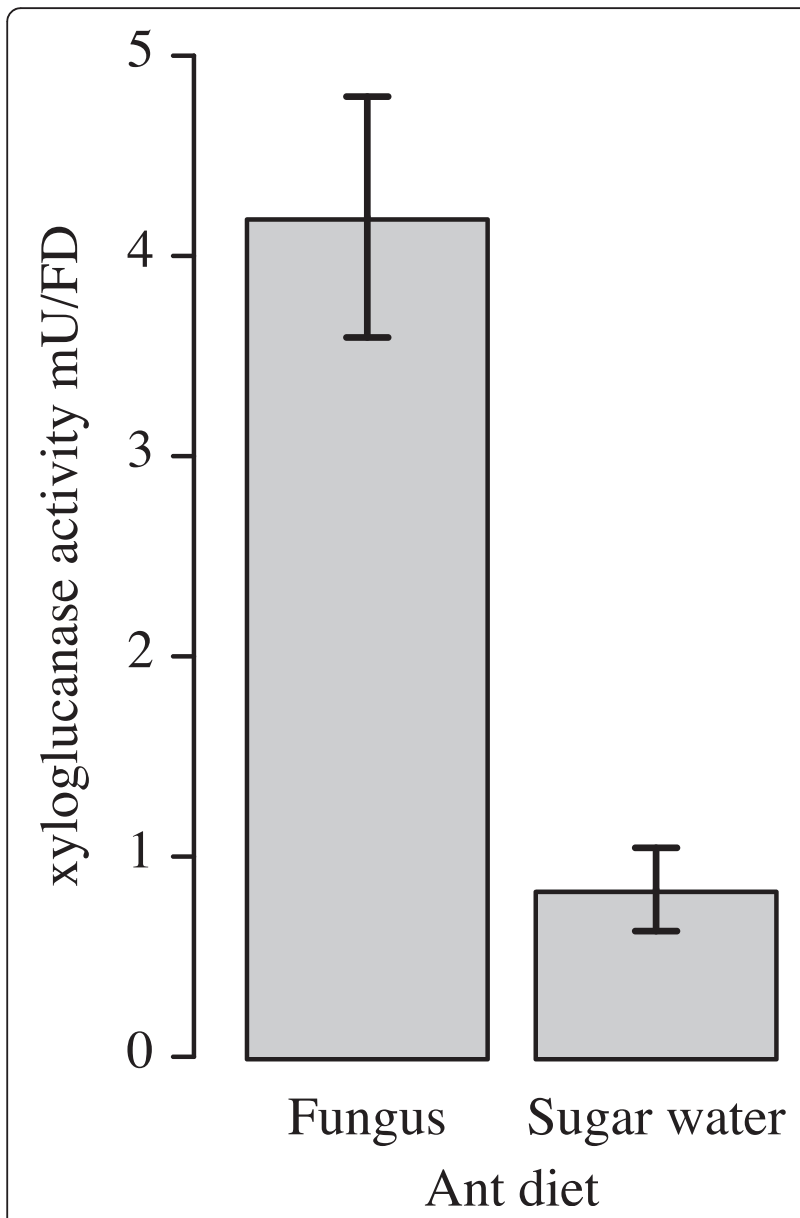

Fig. 2 Xeg1 acitivity in fecal fluid is 4-5 times higher when ants eat fungus garden material. Xyloglucanase activities for fecal fluid produced by large workers of Acromyrmex echinatior provided with either a normal fungus garden diet or with sucrose water for 20 days. A Welch two sample t-test showed a significant reduction in xyloglucanase activity $\left(t_{4.943}=5.276, p<0.01\right)$ when ants were deprived of fungus garden material. Enzyme activity levels are given as milliunits per fecal droplet (mean $\pm \mathrm{SE}, n=5$ colonies)

Several recent studies have confirmed that pectinases in particular have important roles in the pre-digestion of plant material in the top layers of fungus gardens while cellulose remains mostly undigested until these residues have reached the bottom layer and the debris material $[14,16,17,22,23,45]$. Our results show that also xyloglucanases have a higher activity towards the bottom layer of the fungus garden and in the debris material (Fig. 3), complementing an earlier study showing a similar stratification for xylanases [23]. These results imply that the fungus garden can indeed convert xyloglucan into glucose molecules that can be taken up as nutrients by fungal cells, but that this activity is mostly expressed towards the end of the substrate degradation process when other more easily accessible nutrients have already been decomposed. Although many studies have pointed

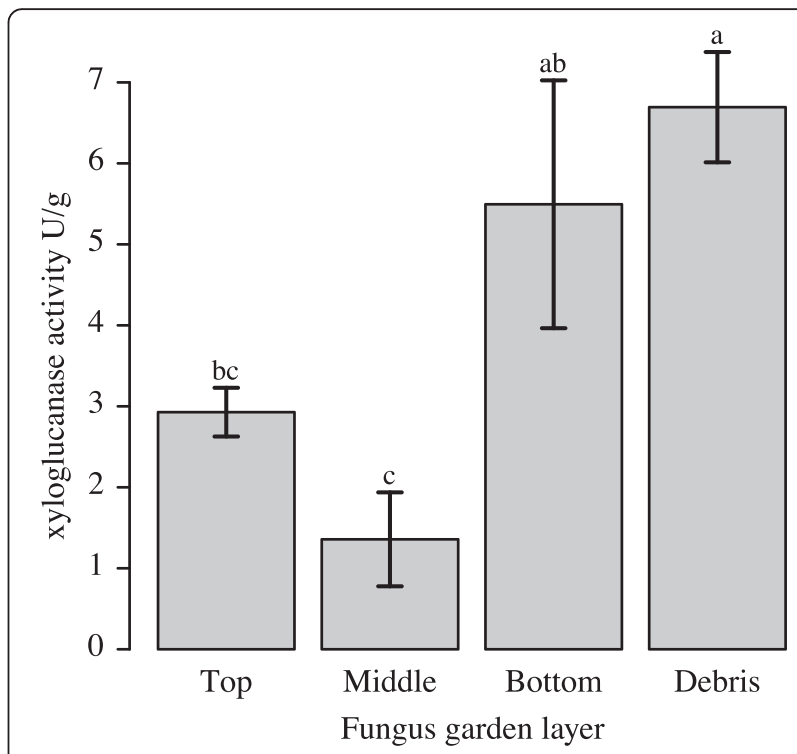

Fig. 3 Xyloglucanase activity is highest in the bottom and discarded layers of fungus gardens. Xyloglucanase activities for the top, middle and bottom layers of Acromyrmex echinatior fungus gardens and debris material. Xyloglucanase activity was relatively low in the top and middle layers and high in the bottom layer and debris material $\left(F_{3,12}=7.246, p<0.01\right)$. Enzyme activity levels are given as units per gram fungus garden material (mean $\pm \mathrm{SE}, n=5$ colonies). Different letters above bars refer to differences in post-hoc tests at $P<0.05$

out that high (hemi-)cellulolytic activity in the bottom of fungus gardens may also be due to bacteria [45-47] or yeasts [48-50], the present study and recent results by Aylward et al. [16] and Grell et al. [17] are consistent in suggesting that a significant fraction of (hemi-)cellulose decomposition in the bottom of gardens is performed by the fungal symbiont itself. Our results also show that hemicellulase activity continues to be high in the bottom layer and debris pile, which suggests that fungal symbiont cells survive in this untended environment in substantial quantities. These activities are unlikely to benefit the ant colony directly as the bottom of fungus gardens hardly produces gongylidia [11], but they make sense from a hygienic perspective as it limits niche space for alternative decomposers that might spread as infections to the bottom of fungus gardens when allowed to get a foothold in the waste piles [17].

In addition to confirming hemi-cellulolytic activity towards the end of the decomposition process, our present study also shows that xyloglucan decomposition is an explicit target in the top of fungus gardens. An even more pronounced gongylidial upregulation of the $x e g 1$ gene (ca. 20 fold) was found in a recent RNA-seq study of leafcutting ant fungal symbionts, where this gene showed the largest difference in expression between gongylidia and mycelium among all genes predicted in the transcriptome [51]. This is an interesting result because, even though the 
GH12 enzyme family includes both xyloglucanases and cellulases, the Xeg1 enzyme specifically catabolizes xyloglucan but not cellulose (Fig. 1), consistent with the hypothesized purpose of just loosening up the plant cell walls to allow hyphal access to the cell interior with proteins and starch $[13,14,17,33]$. At the same time, the sucrose released by early xyloglucan decomposition undoubtedly stimulates hyphal growth in the top of gardens before the hyphae have access to the starch inside the plant cell walls. Taken together these layerspecific enzyme activities confirm that cellulose degradation is not a priority and that decomposition is primarily focused on obtaining nitrogen and possibly other limiting nutrients, but not carbon.

This interpretation of our results follows the general idea that decomposition of organic matter takes place in a stoichiometric manner, which keeps ratios of liberated carbon, nitrogen, phosphorus and other possibly limiting nutrients relatively constant and releases any surplus nonlimiting nutrients into the external environment [52-54]. It is well documented that plant diets offer an excess of carbon relative to nitrogen and phosphorus [52, 55], so that decomposers such as the ant-fungus symbiosis should be under selection to primarily invest in enzymes for acquiring the most limiting nutrients (nitrogen and possibly phosphorus), while adjusting carbon decomposition/liberation to the level needed for achieving stoichiometric equilibrium. Indications of the leaf-cutting ant symbiosis to be nitrogen-limited have emanated from the demonstration of nitrogen-fixing bacteria in the fungus gardens of Atta leaf-cutting ants [56] and other nitrogen conserving bacteria in the guts of Acromyrmex leaf-cutting ants [57]. Depending on the efficiency of these nitrogen preserving bacterial symbionts, it may thus turn out that the availability of phosphorus in the plant substrate is ultimately the most limiting factor for the leafcutting ant symbiosis, but further work will be needed to substantiate this hypotheses.

\section{Conclusion}

The fungal symbiont of the leaf-cutting ant $A$. echinatior provides a single xyloglucanase (Xeg1) to the farming ants by upregulating the expression of this protein in the gongylidia that the ants ingest. Xeg1 is not used by the ants for digestion but for deposition on new leaf-fragment substrate via their fecal fluid, where it contributes to the degradation of recalcitrant plant cell wall polymers. Our results support the idea that the availability of carbon in the form of monosaccharides is not a limiting factor in the ant-fungus-farming symbiosis, which more likely is limited by other nutrients such as nitrogen and phosphorus, and the function of the fecal droplet xyloglucanase is to contribute to the breakdown of plant substrate cell walls to allow the fungus to gain access to the more nutritious intracellular compounds.

\section{Ethics and consent to participate}

Permission to collect ant colonies and export them from Panama to Denmark was given by the Autoridad Nacional del Ambiente y el Mar (ANAM), Panama.

\section{Consent to publish}

Not applicable.

\section{Availability of data and materials}

All the data supporting the findings of this study are contained within the manuscript and its additional file.

\section{Additional file}

Additional file 1: Table S1. List of qPCR primers used in this study, including primer sequences, annealing temperatures and fragment lengths in base pairs. Table S2. qPCR results of Xeg1, Ubc and GAPDH, for the two different fungal tissues, gongylidia and mycelium. Table S3. qPCR results of Xeg1, Ubc and GAPDH, for the top, middle and bottom layers and debris material from ant fungus gardens. Table S4. Xyloglucanase enzyme activity data for ant fecal fluid. Table S5. Xyloglucanase enzyme activity data for the top, middle and bottom layers and debris material from ant fungus gardens. (XLSX $28 \mathrm{~kb}$ )

\section{Abbreviations}

A. echinatior: Acromyrmex echinatior; ANOVA: Analysis of Variance; AZCL: Azurine-Crosslinked; BLAST: Basic Local Alignment Search Tool: cDNA: Complementary Deoxyribonucleic Acid; DNA: Deoxyribonucleic Acid ELISA micro plate reader: Enzyme-linked Immunosorbent Assay micro plate reader; GAL1: Galactokinase; GAPDH: Glyceraldehyde 3-Phosphate Dehydrogenase; GH12: Glycoside Hydrolase Family 12; glht: General Linear Hypotheses; INVSc1: Saccharomyces cerevisiae Yeast strain used in this study; LiOAC: Lithium Acetate; MS/MS: Tandem Mass Spectrometry; PCR: Polymerase Chain Reaction; PEG: Polyethylene Glycol; pYES2: Yeast expression vector used in this study; qPCR: Quantitative Polymerase Chain Reaction; RNA: Ribonucleic Acid; RT-qPCR: Real Time Quantitative Polymerase Chain Reaction; SDS-PAGE: Sodium Dodecyl Sulfate Polyacrylamide Gel Electrophoresis; SE: Standard Error; SMART RACE: Switching Mechanism At the $5^{\prime}$-end of RNA Transcript Rapid Amplification of cDNA Ends; Tris: Tris(hydroxymethyl)aminomethane; Ubc: Ubiquitin; UPM: Universal Primer Mix; URA3: Orotidine 5'-phosphate decarboxylase;

Xeg1: Xyloglucanase described in this study.

Competing interests

The author(s) declare that they have no competing interests.

\section{Authors' contributions}

Conceived and designed the experiments: PWK JJB MS. Performed the experiments: PWK JWMP MS. Analyzed the data: PWK JWMP JJB MS. Contributed reagents/material/analysis tools: PWK JJB MS. Wrote the paper: PWK JJB MS. All authors read and approved the final manuscript.

\section{Authors' information}

PWK is currently employed at the Comparative Plant and Fungal Biology Department, Royal Botanic Gardens, Kew, UK.

\section{Acknowledgements}

We thank the Smithsonian Tropical Research Institute (STRI), Panama, for providing logistic help and facilities to work in Gamboa, and Adelina Rogowska-Wrzesinska, Andrea Lorentzen and Peter Roepstorff for producing and analyzing the mass spectrometry data. 


\section{Funding}

This study was funded by the Danish National Research Foundation (DNRF57) and the ERC (Advanced Grant 323085) to JJB. The funding bodies did not play any role in the design of the study, in the collection, analysis, and interpretation of data or in writing the manuscript.

\section{Author details}

'Centre for Social Evolution, Department of Biology, Copenhagen University, Universitetsparken 15, Copenhagen DK-2100, Denmark. ${ }^{2}$ Laboratory of Genetics, Wageningen University and Research Centre, P.O. Box 309, Wageningen $6700 \mathrm{AH}$, The Netherlands. ${ }^{3}$ Present address: Jodrell Laboratory, Royal Botanic Gardens, Richmond, Kew TW9 3DS, UK.

\section{Received: 26 November 2015 Accepted: 27 April 2016}

\section{Published online: 06 May 2016}

\section{References}

1. Calderón-Cortés N, Quesada M, Watanabe H, Cano-Camacho H, Oyama K. Endogenous plant cell wall digestion: A key mechanism in insect evolution. Annu Rev Ecol Evol S. 2012;43:45-71.

2. Breznak JA. Intestinal microbiota of termites and other xylophagous insects. Annu Rev Microbiol. 1982;36:323-43.

3. Douglas AE. Microbial brokers of insect-plant interactions revisited. J Chem Ecol. 2013;39:952-61.

4. Ohkuma M. Termite symbiotic systems: efficient bio-recycling of lignocellulose. Appl Microbiol Biot. 2003:61:1-9.

5. Noda S, Kitade O, Inoue T, Kawai M, Kanuka M, Hiroshima K, Hongoh Y, Constantino R, Uys V, Zhong J, Kudo T, Ohkuma M. Cospeciation in the triplex symbiosis of termite gut protists (Pseudotrichonympha spp.), their hosts, and their bacterial endosymbionts. Mol Ecol. 2007;16:1257-66.

6. Zhang N, Suh S-O, Blackwell M. Microorganisms in the gut of beetles: evidence from molecular cloning. J Invertebr Pathol. 2003;84:226-33.

7. Grünwald S, Pilhofer M, Höll W. Microbial associations in gut systems of wood- and bark-inhabiting longhorned beetles [Coleoptera: Cerambycidae]. Syst Appl Microbiol. 2010:33:25-34.

8. Biedermann PHW, Klepzig KD, Taborsky M. Fungus cultivation by ambrosia beetles: behavior and laboratory breeding success in three xyleborine species. Environ Entomol. 2009;38:1096-105.

9. Aanen DK, Eggleton P, Rouland-Lefevre C, Guldberg-Froslev T, Rosendahl S, Boomsma JJ. The evolution of fungus-growing termites and their mutualistic fungal symbionts. Proc Natl Acad Sci USA. 2002;99:14887-92.

10. De Fine Licht HH, Boomsma JJ. Forage collection, substrate preparation, and diet composition in fungus-growing ants. Ecol Entomol. 2010;35:259-69.

11. De Fine Licht HH, Schiøtt M, Rogowska-Wrzesinska A, Nygaard S, Roepstorff P, Boomsma JJ. Laccase detoxification mediates the nutritional alliance between leaf-cutting ants and fungus-garden symbionts. Proc Natl Acad Sci U S A. 2013;110:583-7.

12. De Fine Licht HH, Schiøtt M, Mueller UG, Boomsma JJ. Evolutionary transitions in enzyme activity of ant fungus gardens. Evolution. 2010;64:2055-69.

13. Schiøtt M, Rogowska-Wrzesinska A, Roepstorff P, Boomsma JJ. Leaf-cutting ant fungi produce cell wall degrading pectinase complexes reminiscent of phytopathogenic fungi. BMC Biol. 2010;8:156.

14. Moller IE, De Fine Licht HH, Harholt J, Willats WGT, Boomsma JJ. The dynamics of plant cell-wall polysaccharide decomposition in leaf-cutting ant fungus gardens. PLoS One. 2011;6:e17506.

15. Kooij PW, Schiøtt M, Boomsma JJ, De Fine Licht HH. Rapid shifts in Atta cephalotes fungus-garden enzyme activity after a change in fungal substrate (Attini, Formicidae). Insect Soc. 2011;58:145-51.

16. Aylward FO, Burnum-Johnson KE, Tringe SG, Teiling C, Tremmel DM, Moeller JA, Scott JJ, Barry KW, Piehowski PD, Nicora CD, Malfatti SA, Monroe ME, Purvine SO, Goodwin LA, Smith RD, Weinstock GM, Gerardo NM, Suen G, Lipton MS, Currie CR. Leucoagaricus gongylophorus produces diverse enzymes for the degradation of recalcitrant plant polymers in leaf-cutter ant fungus gardens. Appl Environ Microb. 2013;79:3770-8.

17. Grell MN, Linde T, Nygaard S, Nielsen KL, Boomsma JJ, Lange L. The fungal symbiont of Acromyrmex leaf-cutting ants expresses the full spectrum of genes to degrade cellulose and other plant cell wall polysaccharides. BMC Genomics. 2013;14:928.

18. Kooij PW, Liberti J, Giampoudakis K, Schiøtt M, Boomsma JJ. Differences in forage-acquisition and fungal enzyme activity contribute to niche segregation in Panamanian leaf-cutting ants. PLoS One. 2014;9:e94284.
19. Lange L, Grell MN. The prominent role of fungi and fungal enzymes in the ant-fungus biomass conversion symbiosis. Appl Microbiol Biot. 2014;98:4839-51.

20. Nagamoto NS, Garcia MG, Forti LC, Verza SS, Noronha NC, Rodella RA. Microscopic evidence supports the hypothesis of high cellulose degradation capacity by the symbiotic fungus of leaf-cutting ants. J Biol Res-Thessalon. 2011;16:308-12.

21. Boyd ND, Martin MM. Faecal proteinases of the fungus-growing ant, Atta texana: properties, significance and possible origin. Insect Biochem. 1975;5:619-35.

22. Martin MM, Boyd ND, Gieselmann MJ, Silver R. Activity of faecal fluid of a leaf-cutting ant toward plant cell wall polysaccharides. J Insect Physiol. 1975;21:1887-92.

23. Schiøtt $M$, De Fine Licht $H H$, Lange $L$, Boomsma JJ. Towards a molecular understanding of symbiont function: Identification of a fungal gene for the degradation of xylan in the fungus gardens of leaf-cutting ants. BMC Microbiol. 2008:8:40.

24. Weber NA. Fungus-growing ants. Science. 1966;153:587-604.

25. Mueller UG, Gerardo NM, Aanen DK, Six DL, Schultz TR. The evolution of agriculture in insects. Annu Rev Ecol Evol S. 2005;36:563-95.

26. Kooij PW, Aanen DK, Schiøtt M, Boomsma JJ. Evolutionarily advanced ant farmers rear polyploid fungal crops. J Evolution Biol. 2015;28:1911-24.

27. Lucia Della TMC, Gandra LC, Guedes RNC. Managing leaf-cutting ants: Peculiarities, trends and challenges. Pest Manag Sci. 2014;70:14-23.

28. Fowler HG, Pagani MI, Da Silva OA, Forti LC, Da Silva VP, De Vasconcelos HL. A pest is a pest is a pest? The dilemma of Neotropical leaf-cutting ants: keystone taxa of natural ecosystems. Environ Manage. 1989;13:671-5.

29. Quinlan R, Cherrett JM. Aspects of the symbiosis of the leaf-cutting ant Acromyrmex octospinosus (Reich) and its food fungus. Ecol Entomol. 1978:3:221-30

30. Quinlan $R$, Cherrett JM. The role of fungus in the diet of the leaf-cutting ant Atta cephalotes (L.). Ecol Entomol. 1979;:1151-60.

31. Bass M, Cherrett JM. Fungal hyphae as a source of nutrients for the leafcutting ant Atta sexdens. Physiol Entomol. 1995;20:1-6.

32. Martin MM, Jones CG, Bernays EA. The evolution of cellulose digestion in insects [and discussion]. Philos T Roy Soc B. 1991;333:281-8.

33. Kooij PW, Rogowska-Wrzesinska A, Hoffmann D, Roepstorff P, Boomsma JJ, Schiøtt M. Leucoagaricus gongylophorus uses leaf-cutting ants to vector proteolytic enzymes towards new plant substrate. ISME J. 2014;8:1032-40.

34. Gilbert HJ, Stålbrand H, Brumer H. How the walls come crumbling down: recent structural biochemistry of plant polysaccharide degradation. Curr Opin Plant Biol. 2008;11:338-48.

35. Hayashi T, Kaida R. Functions of xyloglucan in plant cells. Mol Plant. 2011;4:17-24.

36. Rodrigues A, Carletti CD, Bueno OC, Pagnocca FC. Leaf-cutting ant faecal fluid and mandibular gland secretion: effects on microfungi spore germination. Braz J Microbiol. 2008;39:64-7.

37. Nygaard S, Zhang G, Schiøtt M, Li C, Wurm Y, Hu H, Zhou J, Ji L, Qiu F, Rasmussen M, Pan H, Hauser F, Krogh A, Grimmelikhuijzen CJP, Wang J, Boomsma JJ. The genome of the leaf-cutting ant Acromyrmex echinatior suggests key adaptations to advanced social life and fungus farming. Genome Res. 2011;21:1339-48.

38. Perkins J, Kohl M: ReadqPCR: Read qPCR data. 2011. http://www.bioconductor. org/packages/2.14/bioc/html/ReadqPCR.html. Accessed 29 Apr. 2016.

39. Kohl M, Perkins J: NormqPCR: Functions for normalisation of RT-qPCR data. 2011. http://www.bioconductor.org/packages/devel/bioc/html/NormqPCR. html. Accessed 29 Apr. 2016.

40. Schmittgen TD, Zakrajsek BA. Effect of experimental treatment on housekeeping gene expression: validation by real-time, quantitative RT-PCR. J Biochem Bioph Meth. 2000;46:69-81.

41. Hothorn T, Bretz F, Westfall P. Simultaneous inference in general parametric models. Biometrical J. 2008;50:346-63.

42. Livak KJ, Schmittgen TD. Analysis of relative gene expression data using real-time quantitative PCR and the 2(-Delta Delta C(T)) Method. Methods. 2001:25:402-8.

43. Schiestl RH, Gietz RD. High efficiency transformation of intact yeast cells using single stranded nucleic acids as a carrier. Curr Genet. 1989;16:339-46.

44. Heredia A, Jiménez A, Guillén R. Composition of plant cell walls. Z Lebensm Unters Forsch. 1995:200:24-31.

45. Suen G, Scott JJ, Aylward FO, Adams SM, Tringe SG, Pinto-Tomás AA, Foster CE, Pauly M, Weimer PJ, Barry KW, Goodwin LA, Bouffard P, Li L, Osterberger J, Harkins TT, Slater SC, Donohue TJ, Currie CR. An insect herbivore microbiome with high plant biomass-degrading capacity. PLoS Genet. 2010; 6(9):e1001129. 
46. Bacci Jr M, Ribeiro SB, Casarotto M, Pagnocca FC. Biopolymer-degrading bacteria from nests of the leaf-cutting ant Atta sexdens rubropilosa. Braz J Med Biol Res. 1995;28:79-82.

47. Aylward FO, Burnum-Johnson KE, Scott JJ, Suen G, Tringe SG, Adams SM, Barry KW, Nicora CD, Piehowski PD, Purvine SO, Starrett GJ, Goodwin LA, Smith RD, Lipton MS, Currie CR. Metagenomic and metaproteomic insights into bacterial communities in leaf-cutter ant fungus gardens. ISME J. 2012;6: 1688-701.

48. Carreiro SC, Pagnocca FC, Bueno OC, Bacci Jr M, Hebling MJA, Da Silva OA. Yeasts associated with nests of the leaf-cutting ant Atta sexdens rubropilosa Forel, 1908. Anton Leeuw Int J G. 1997;71:243-8.

49. Middelhoven WJ, Fonseca A, Carreiro SC, Pagnocca FC, Bueno OC Cryptococcus haglerorum, sp. nov., an anamorphic basidiomycetous yeast isolated from nests of the leaf-cutting ant Atta sexdens. Anton Leeuw Int J G. 2003;83:167-74.

50. Mendes TD, Rodrigues A, Dayo-Owoyemi I, Marson FAL, Pagnocca FC. Generation of nutrients and detoxification: possible roles of yeasts in leafcutting ant nests. Insects. 2012;3:228-45.

51. De Fine Licht HH, Boomsma JJ, Tunlid A. Symbiotic adaptations in the fungal cultivar of leaf-cutting ants. Nat Commun. 2014;5:5675.

52. Manzoni S, Trofymow JA, Jackson RB, Porporato A. Stoichiometric controls on carbon, nitrogen, and phosphorus dynamics in decomposing litter. Ecol Monogr. 2010;80:89-106.

53. Hartman WH, Richardson CJ. Differential nutrient limitation of soil microbial biomass and metabolic quotients (qCO2): Is there a biological stoichiometry of soil microbes? PLoS One. 2013:8:e57127.

54. Sinsabaugh RL, Manzoni S, Moorhead DL, Richter A. Carbon use efficiency of microbial communities: stoichiometry, methodology and modelling. Ecol Lett. 2013;16:930-9.

55. Bell C, Carrillo Y, Boot CM, Rocca JD, Pendall E, Wallenstein MD. Rhizosphere stoichiometry: are C : N :P ratios of plants, soils, and enzymes conserved at the plant species-level? New Phytol. 2014;201:505-17.

56. Pinto-Tomás AA, Anderson MA, Suen G, Stevenson DM, Chu FST, Cleland WW, Weimer PJ, Currie CR. Symbiotic nitrogen fixation in the fungus gardens of leaf-cutter ants. Science. 2009:326:1120-3.

57. Sapountzis P, Zhukova M, Hansen LH, Sørensen SJ, Schiøtt M, Boomsma JJ. Acromyrmex leaf-cutting ants have simple gut microbiota with nitrogenfixing potential. Appl Environ Microb. 2015;81:5527-37.

\section{Submit your next manuscript to BioMed Central and we will help you at every step:}

- We accept pre-submission inquiries

- Our selector tool helps you to find the most relevant journal

- We provide round the clock customer support

- Convenient online submission

- Thorough peer review

- Inclusion in PubMed and all major indexing services

- Maximum visibility for your research

Submit your manuscript at www.biomedcentral.com/submit

C Biomed Central 